\title{
Characterization and evaluation of polymorphic microsatellite markers in the anadromous fish Spirinchus thaleichthys
}

\author{
Joshua A. Israel • Bernie May
}

Received: 23 April 2010/ Accepted: 5 May 2010/Published online: 28 May 2010

(C) The Author(s) 2010. This article is published with open access at Springerlink.com

\begin{abstract}
We describe seventeen microsatellite loci isolated from longfin smelt, Spirinchus thaleichthys, which is an anadromous fish inhabiting estuarine and nearshore marine waters along the western Pacific coast. Five to 16 alleles per locus were detected, the expected heterozygosity ranged from $0.33-0.93$, and moderate levels of differentiation were found between collections. These polymorphic microsatellites will provide useful tools for studying population genetic structure at ecological scales within wild and propagated populations.
\end{abstract}

Keywords Longfin smelt · Conservation · Propagation · Pelagic Organism decline

While longfin smelt, Spirinchus thaleichthys, remain among one of the more common pelagic native species in the San Francisco Bay-Delta, CA, a recent significant population decline at the southern edge of its distribution has been observed (Sommer et al. 2007). This species was recently listed as Threatened under the California Endangered Species Act (CDFG 2009) although a petition for listing under the U.S. Endangered Species Act remains undetermined. Longfin smelt show a diversity of migratory patterns and anadromous and resident populations are native to the Pacific coast of North America. These fish are

J. A. Israel · B. May

Department of Animal Science, Genomic Variation Laboratory,

1 Shields Ave, Davis, CA 95616, USA

\section{J. A. Israel ( $₫)$}

Applied Science Branch, Bureau of Reclamation,

U.S. Department of Interior, 2800 Cottage Way, MP-151,

Sacramento, CA 95825, USA

e-mail: jaisrael@ucdavis.edu; JAIsrael@usbr.gov semelparous, typically undergo a two-year life cycle and spawn in freshwater and the low salinity zone before larval and juvenile fishes are transported downstream to nursery habitats (Hobbs et al. accepted). Juveniles move out of the San Francisco Bay into nearshore coastal waters, while others seem to reside in the Bay-Delta (Moyle 2002). Little is known about San Francisco longfin smelt spawning habitats and ecology, although adults presumably migrate back to the low salinity zone immediately prior to spawning (Rosenfield and Baxter 2007). A better-studied resident population inhabits Lake Washington, WA (Chigbu 2000; Chigbu and Sibley 1994; Chigbu et al. 1998). While longfin smelt are reported to be widespread in nearshore coastal regions and estuaries, few fish have been observed and fewer spawning populations have been identified between San Francisco Bay and Lake Washington (USFWS 1994, CDFG 2009).

Whole genomic DNA was extracted from fin tissue of longfin smelt from Suisun March, CA using the PureGene Genomic DNA Purification Kit. Six libraries enriched for one of four tetranucleotide repeat motifs [AAAC, CAGA, CATC, TAGA] were constructed, screened, and sequenced by Genetic Identification Services according to Börk et al. (2008). Sequences were analyzed with SEQUENCHER version 4.7 (Gene Code Corporation) to remove duplicate sequences. Repeat regions in sequences were identified with MREPS version 2.5 (Kolpakov et al. 2003) and primer pairs flanking these regions were created with PRIMER 3 (Rozen and Skaletsky 2000) for 200 of 227 novel sequences. For screening, one of four $5^{\prime}$ modifications (universal primers: T7T, T7P, M13, SP6) was added to the end of each forward primer using the method of Schuelke (2000), which incorporated a $5^{\prime}$ fluorophore during polymerase chain reaction (PCR). Each primer set was initially tested on eight longfin smelt samples to determine 


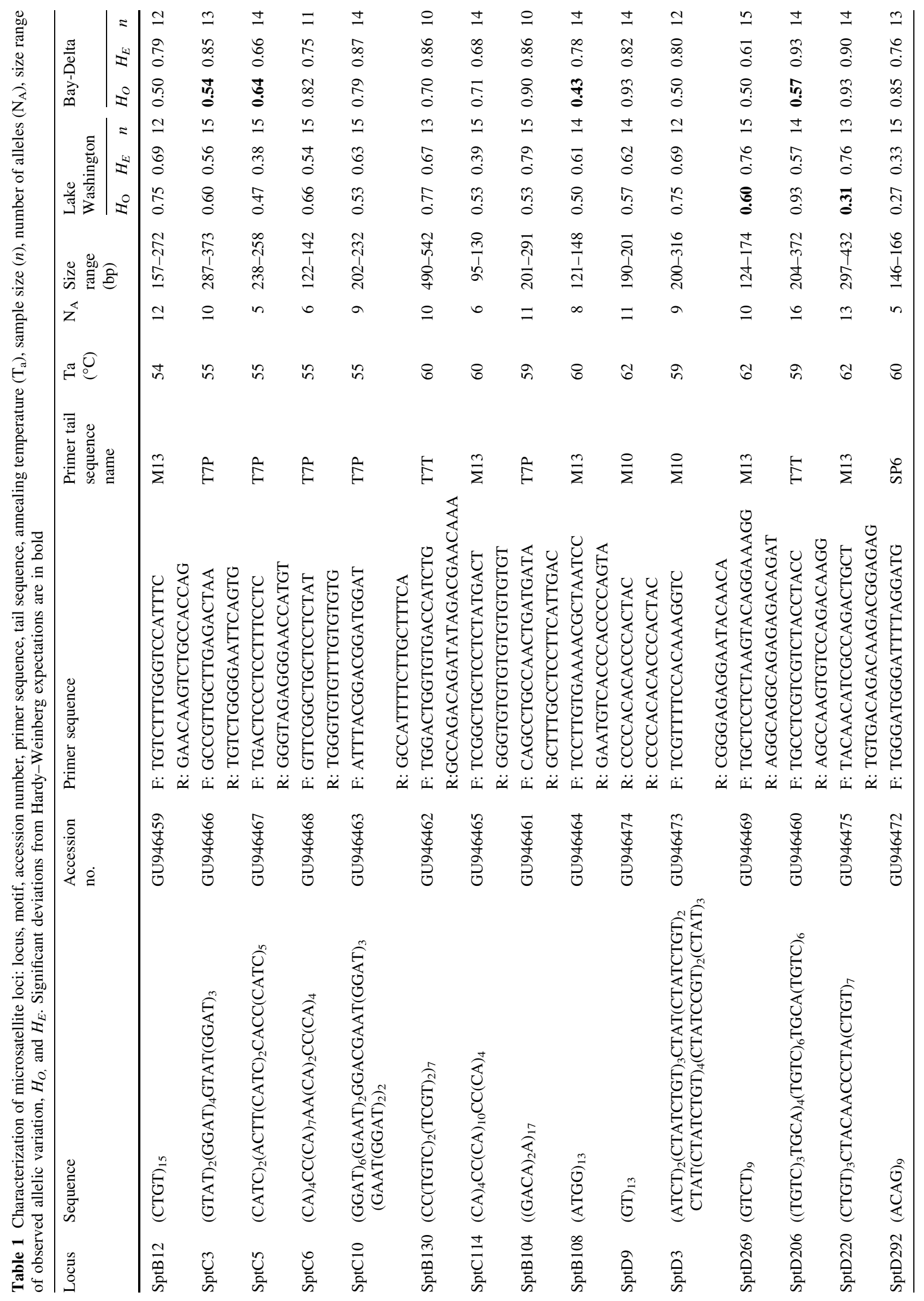




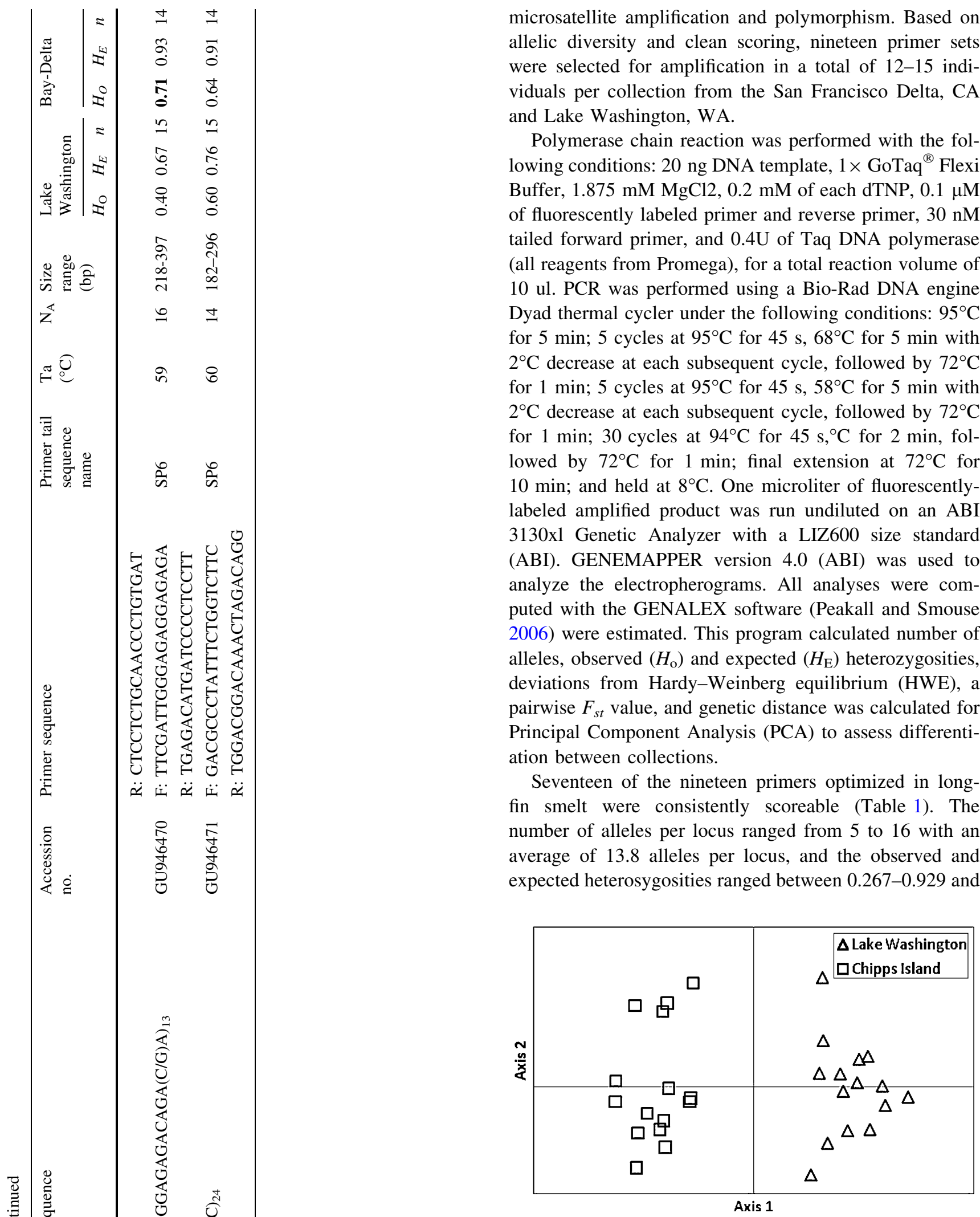

Fig. 1 Principal Component Analysis of two collections of longfin smelt $(n=15$ each). Axis 1 accounts for $33.1 \%$ of the genetic covariance, while Axis 2 explains an additional $16.2 \%$ of the total variation 
0.331-0.926, respectively. Seven loci deviated significantly from Hardy-Weinberg expectations. A pairwise $F_{s t}$ value of 0.091 was calculated between the two collections, and visualization of genetic distances using Principal Component Analysis supports moderate levels of differentiation between these two collection sites (Fig. 1). Genetic analysis of these collections suggested genetic isolation between locations, which are separated by over 800 miles of coast. These results are concordant with a previous allozyme study (Stanley et al. 1995), and support the distinctiveness and genetic isolation of the longfin smelt populations in these locations. These genetic markers will be useful for further evaluation of spatial and temporal genetic variation in $S$. thaleichthys and characterizing relationships among individuals in populations.

Acknowledgments This study was supported by the Interagency Ecological Program (DWR Award\# 4600008137). The authors are indebted to Denice Lin, John Pedroia, and Emily Ringelman for laboratory assistance. Tom Quinn, Kathy Hieb, Jim Hobbs, and Randy Baxter are greatly appreciated for providing samples.

Open Access This article is distributed under the terms of the Creative Commons Attribution Noncommercial License which permits any noncommercial use, distribution, and reproduction in any medium, provided the original author(s) and source are credited.

\section{References}

Börk K, Drauch A, Israel JA, Pedroia J, Rodzen J, May B (2008) Development of new microsatellite primers for green and white sturgeon. Conserv Genet 9:973-979

CDFG (2009) A status review of the longfin smelt (Spirinchus thaleichthys) in California. Report to the fish and game commission. January 23, 2009, pp 45
Chigbu P (2000) Population biology of longfin smelt and aspects of the ecology of other major planktivorous fishes in Lake Washington. J Freshwater Ecol 15:543-557

Chigbu P, Sibley TH (1994) Relationship between abundance, growth, egg size, and fecundity in a landlocked population of longfin smelt, Spirinchus thaleichthys. J Fish Biol 1:1-15

Chigbu P, Sibley TH, Beauchamp DA (1998) Abundance and distribution of Neomysis mercedis and a major predator, longfin smelt (Spirinchus thaleichthys) in Lake Washington. Acta Hydrobiol 386:167-182

Hobbs JA, Lewis LS, Ikemiyagi N, Sommer T, Baxter R (accepted) The use of otolith strontium isotopes $(87 \mathrm{Sr} / 86 \mathrm{Sr})$ to identify nursery habitat for a threatened estuarine fish. Environ Biol Fishes

Kolpakov R, Bana G, Kucherov G (2003) mreps: efficient and flexible detection of tandem repeats in DNA. Nucleic Acids Re 31:26783672

Moyle PB (2002) Inland fishes of California, 2nd edn. University of California Press, Berkeley, CA

Peakall R, Smouse PE (2006) GENALEX 6: genetic analysis in Excel. Population genetic software for teaching and research. Mol Ecol Notes 6:288-295

Rosenfield JA, Baxter R (2007) Population dynamics and distribution patterns of Longfin smelt in the San Francisco estuary. Trans Am Fish Soc 136:1577-1592

Rozen S, Skaletsky H (2000) Primer3 on the WWW for general users and for biologist programmers. In: Krawetz S, Misener S (eds) Methods in molecular biology. Humana Press, Totowa, p 365

Schuelke M (2000) An economic method for the fluorescent labeling of PCR fragments. Nat Biotechnol 18:233-234

Sommer T, Armor C, Baxter R et al (2007) The collapse of pelagic fishes in the upper San Francisco Estuary. Fisheries 32:270-277

Stanley SE, Moyle PB, Shafer HB (1995) Allozyme analysis of delta smelt, Hypomesus transpacificus and Longfin smelt, Spirinchus thaleichthys in the Sacramento-San Joaquin Estuary, California. Copeia 1995(2):390-396

USFWS (1994) Endangered and Threatened Wildlife and Plants; Notice of 1-Year Finding on a Petition to List the Longfin Smelt. U.S. Fish and Wildlife Service 